DOI: $10.15290 /$ bsl.2018.12.15

\author{
Monika Justyna Roman \\ Wydział Filologiczny \\ Uniwersytet w Białymstoku \\ e-mail: monikajustynaroman@gmail.com \\ ORCID: 0000-0002-6151-6014
}

\title{
Popkultura jako medium pamięci regionalnej na przykładzie Białegostoku
}

Pamięć zbiorowa nie istnieje bez mediów - konstatuje Astrid Erll w swoim tekście Literatura jako medium pamięci zbiorowej:

W okolicznościach społecznych i kulturowych (kultura jako fenomen pamięci - collective memory) ustanowienie i cyrkulacja wspólnej wersji przeszłości oraz wiedzy na ten temat stają się możliwe dopiero dzięki mediom - dzięki oralności i pisemności, które są prastarymi i podstawowymi mediami służącymi do utrwalania mitów fundacyjnych dla kolejnych pokoleń; dzięki drukowi, radiu, telewizji i Internetowi, które transmitują wersje przeszłości danej społeczności $\mathrm{w}$ dalszych kręgach społeczeństwa; i wreszcie dzięki mediom symbolicznym jak pomniki, wokół których odbywają się praktyki pamięci zbiorowej, często tej zrytualizowanej ${ }^{1}$.

Zdaniem Erll, nie wszystkie media pamięci są równie wpływowe, pełnią jednak rolę instancji pośredniczących między indywidualnym a zbiorowym wymiarem pamiętania. Bowiem osobiste wspomnienia nabierają kolektywnego znaczenia dopiero dzięki medialnej reprezentacji i dystrybucji²

\footnotetext{
1 A. Erll, Literatura jako medium pamięci zbiorowej, przeł. M. Saryusz-Wolska, w: Pamięć zbiorowa i kulturowa. Wspótczesna perspektywa niemiecka, red. M. Saryusz-Wolska, Kraków 2009, s. 215.

2 Tamże, s. 216.
} 
W przeciwieństwie do Aleidy Assmann³, która uważa, że teksty kulturowe, czyli dzieła literatury wysokiej nieustannie obecne $\mathrm{w}$ obiegu edukacyjnym odgrywają główną rolę w kształtowaniu pamięci zbiorowej, Astrid Erll podkreśla znaczenie kultury popularnej i nowych mediów. Stanowią one o powstawaniu licznych reprezentacji przeszłości, a także o konkretnym wymodelowaniu pamięci zbiorowej, która bez nich nie może dziś istnieć. Erll podkreśla, iż współcześnie funkcji tej nie pełnią już tylko "teksty kultury" opisywane przez Assmannów, wchodzące w skład kanonu, lecz utwory, które są przede wszystkim poczytne i popularne. Badaczka wyznacza im kluczową rolę w procesie utrwalania i przekazywania zasobów pamięci, rolę porównywalną z działalnością instytucji (i konkurencyjną wobec nich), np. muzeów, mających kształtować i transmitować kulturowe przekazy o przeszłości:

To właśnie literatura trywialna sięga do zasobów symbolicznych, przypisywanych pamięci kulturowej. Ona bowiem tworzy i umacnia mity oraz przekazuje schematy typowe dla danej kultury. Widać zatem, że pamięć o ugruntowanej przeszłości i zbiorowych konstrukcjach znaczeniowych o charakterze normatywnym, jak i formatywnym jest w skali całego społeczeństwa przekazywana bardziej na gruncie popularnych mediów cyrkulacyjnych aniżeli poprzez instytucjonalne media magazynujące ${ }^{4}$.

Można więc stwierdzić, że to właśnie media popularne (np. komiks, film, muzyka pop, hip-hop etc.) dzięki większemu zasięgowi oddziaływania mogą łatwiej i szybciej wprowadzać, a następnie utrwalać $\mathrm{w}$ pamięci zbiorowej konkretne wersje przeszłości. Tworzą one tym samym rodzaj „pamięci potocznej" (używam tutaj kategorii Barbary Szackiej), czyli takiej, która jest obecna w "przekazach publicznych - przemówieniach politycznych, powieściach, filmach, serialach telewizyjnych, publikacjach medialnych itp." 5 .

Kultura popularna stała się więc jednym ze sposobów reprezentacji, bez których trudno byłoby sobie dzisiaj wyobrazić funkcjonowanie pamięci zbiorowej. Należy jednak zauważyć, że przedstawienie związków popkultury ze zjawiskami i procesami o charakterze memorialnym jest zadaniem niezwykle

3 Zob. A. Assmann, Metafory, modele i media pamięci, przeł. Z. Dziewanowska-Stefańczyk, w: tejże, Między historiq a pamięcia. Antologia, red. i posłowie M. Saryusz-Wolska, Warszawa 2013, s. 89-126.

4 A. Erll, Literatura jako medium pamięci zbiorowej, s. 233.

5 B. Szacka, II wojna światowa w pamięci rodzinnej, w: Między codziennościa a wielka historia. Druga wojna światowa w pamięci zbiorowej społeczeństwa polskiego, red. P.T. Kwiatkowski, L.M. Nijakowski, B. Szacka, A. Szpociński Gdańsk-Warszawa 2010, s. 82-83. 
złożonym i wieloaspektowym. Ze względu na specyfikę każdego z nośników kultury popularnej, do analizowania tego rodzaju mediów pamięci często brakuje gotowych narzędzi, a ich badanie nie obywa się bez przeszkód ${ }^{6}$. Na problem ten zwracała uwagę m.in. Magdalena Saryusz-Wolska, wskazując trudności, które napotyka pamięcioznawca zajmujący się filmem. Zdaniem autorki, powstają one między innymi dlatego, że prace Assmannów, którzy zbudowali podstawy współczesnych badań nad pamięcią kulturową, opierają się głównie na mediach pisemnych, tekstowych - a np. wizualne zostały przez nich zmarginalizowane - co wynika z przekonania, że pełnią one $\mathrm{w}$ historii pamięci rolę ważniejszą niż pozostałe. $\mathrm{W}$ konsekwencji, badacze podążający śladem Assmannów rzadko sięgają do materiału innego niż literatura. Zależność ta staje się szczególnie dojmująca i problematyczna w obszarze kultury popularnej

\section{Między kulturą niską a wysoką. Popkulturowe media pamięci}

Być może omijanie przekazów nietekstowych wynika również z wciąż istniejącej opozycji (pisał o niej m.in. Pierre Bourdieu ${ }^{8}$ ) pomiędzy kulturą „niską" a „wysoką", „popularną" a „elitarną", która jest mocno zakorzeniona w praktykach kulturowych i instytucjonalnych". A przecież to właśnie kultura popularna, ze względu na swój egalitarny charakter, ma duży udział w kształtowaniu pamięci zbiorowej ${ }^{10}$.

${ }^{6}$ O złożoności badań nad komiksem pisał m.in. K. Skrzypczyk w artykule Komiksologia, czyli komiks w ujęciu teoretyczno-badawczym, http://www.zeszytykomiksowe.org/sklad/skrzypczyksympozja.pdf [dostęp 30.06.2018]; o kierunkach badań nad polskim rapem zob. S. Wójtowicz, O kierunkach badan literaturoznawczych nad hip-hopem, w: Hip-hop w Polsce. Od blokowisk do kultury popularnej, red. M. Miszczyński, Warszawa 2014.

7 M. Saryusz-Wolska, Zapomnieć się w pamięci, „Kultura Współczesna” 2010, nr 1. Por. też. J. Kałążny, Kategoria pamięci zbiorowej w badaniach literaturoznawczych, „Kultura Współczesna” 2007, nr 3.

8 P. Bourdieu, Dystynkcja. Społeczna krytyka władzy sadzenia, przeł. P. Biłos, Warszawa 2005.

9 M. Jutkiewicz, Paradoks dystynkcji. Komiks na rynku kultury w Polsce, „Teksty Drugie” 2017, nr 5, s. 89.

10 Badaniami nad popkulturowymi formami pamięci zajmują się naukowcy z Uniwersytetu Warmińsko-Mazurskiego w Olsztynie, którzy co dwa lata organizują na ten temat konferencje naukowe.

Bourdieu wyróżnił jeszcze jedno pole produkcji kulturowej - dzieła nie należące do „najniższej” kategorii, nie będące jednak arcydziełami, czyli tzw. sztukę średnią, do której zalicza się jazz, kino, science fiction czy komiks. 
O tym, jak wielką siłą ona dysponuje, świadczy chociażby oddziaływanie filmu Lista Schindlera Stevena Spielberga, który przyciągnął do kin miliony widzów na całym świecie, co z kolei, jak twierdzi Elżbieta Nieroba w artykule Przeszłość w zwierciadle kultury popularnej, bezpośrednio przełożyło się na wzrost zainteresowania tematyką Holocaustu ${ }^{11}$. Świadczyć o nim może - gdy spojrzymy na statystyki podawane na stronie Miejsca Pamięci Auschwitz-Birkenau - trzykrotny wzrost liczby odwiedzających byłe obozy koncentracyjne w minionej dekadzie (w 2001 roku 492500 osób, a w 2010 już 13800001 , w $20141,5 \mathrm{mln})^{12}$.

Na polskim gruncie skuteczność propagowania narracji historycznych za pomocą form kultury popularnej wyraźnie widać na przykładzie działalności Muzeum Powstania Warszawskiego. W momencie jego powoływania określenie „polityka historyczna” nie istniało jeszcze w debacie publicznej, ale Muzeum stanowi doskonały jej przykład. Należna żołnierzom chwała i pamięć o ich odważnym, szlachetnym czynie z założenia „miała zostać przekuta w pamięć kulturową, integrującą na nowo narodową wspólnotę"13. Muzeum, określane jako „najnowocześniejsze w Polsce”, promuje swoją działalność wykorzystując właśnie media kultury popularnej - komiks i muzykę ${ }^{14}$. Do kanonu "powstańczego" rapu weszły już takie piosenki, jak Sierpniowe niebo Bilona czy też 63 dni chwały, wykonywane przez niego w towarzystwie zespołu Hemp Gru. Ważną rolę w propagowaniu pamięci o Powstaniu Warszawskim pełni również komiks - Muzeum zorganizowało już 5 edycji konkursu Powstanie '44 w komiksie, po każdej z nich ukazuje się Antologia prac konkursowych ${ }^{15}$.

11 E. Nieroba, Wprowadzenie. Przeszłość w zwierciadle kultury popularnej, w: Targowisko przeszłości, red. E. Nieroba, Warszawa 2011.

12 http://70.auschwitz.org/index.php?option=com_content\&view=article\&id=73\&Itemid=17 6\&lang=pl [dostęp 30.06.2018].

13 I. Kurz, Przepisywanie Pamięci. Przypadek Muzeum Powstania Warszawskiego, „Kultura Współczesna" 2007, nr 3, s. 3.

14 Muzeum Powstania Warszawskiego z okazji kolejnych rocznic wybuchu Powstania inicjuje wydawanie albumów muzycznych związanych z tym wydarzeniem: https://kultura.onet.pl/ muzyka/gatunki/pop/piosenki-o-powstaniu-warszawskim-7-plyt-ktore-warto-poznac/2k357ns [dostęp 30.06.2018].

15 Do najbardziej popularnych w Polsce twórców "patriotycznego" rapu należy Tadeusz Polkowski, który wydaje płyty pod pseudonimem "Tadek". Jego kariera rozpoczęła się w 2000 roku, kiedy założył zespół „Firma”, tworzący w estetyce tzw. gangstarapu - „Tadek" i jego koledzy to twórcy bardzo popularnego skrótu "JP", który oznacza "Jebać Policję". W 2011 roku Polkowski rozpoczął działalność solową. W 2012 roku ukazała się jego płyta Niewygodna prawda, która była dołączona do czasopisma „Magna Polonia”, związanego z Obozem Narodowo-Radykalnym, a patronat nad wydawnictwem objęły urzędy takich miast, jak Gdy- 
Można sądzić, że wykorzystywanie do popularyzacji pamięci o Powstaniu Warszawskim (i nie tylko o nim) form kultury popularnej, jakimi są hip-hop i komiks, wynika przede wszystkim z bardzo szerokiego zasięgu ich oddziaływania. Muzyka hip-hopowa zyskała taki oddźwięk, ponieważ przez lata funkcjonowania $\mathrm{w}$ polskiej kulturze zdołała połączyć środowiska i ludzi o odmiennym statusie materialnym, wykształceniu, pochodzeniu i wieku, stając się jednocześnie medium kształtującym opinie i postawy Polaków ${ }^{16}$. Ze względu na swój prosty i ekspresywny język, przekaz hip-hopu nie stwarza barier komunikacyjnych, jest powszechnie rozumiany i chętnie słuchany. Masowy odbiór rap zyskał m.in. dzięki otwartemu dostępowi do komputerów i Internetu, gdzie artyści mogą publikować bez cenzury (np. ze strony wytwórni), zyskując tym większą wiarygodność wśród słuchaczy ${ }^{17}$.

Poetykę komiksu w przeszłości już wykorzystywano nie tylko do opowiadania bijących rekordy sprzedaży rozrywkowych i fikcyjnych historii o superbohaterach ${ }^{18}$, ale też do rozpowszechniania poważnych, nierzadko propagandowych treści ${ }^{19}$. Współczesny komiks coraz częściej traktowany jest jako medium, za pomocą którego opowiada się o przeszłości, zaś tematami komiksowych narracji stały się II wojna światowa, Holocaust, Powstanie Warszawskie czy PRL. Często zatem autorzy tego rodzaju komiksów akcję sytuują w centrum wydarzeń, które zmieniły bieg dziejów. Za przykład niech posłuży komiks Arta Spiegelmana Maus, który w roku 1992 został wyróżniony prestiżową Nagrodą Pulitzera i przetłumaczony na wiele języków ${ }^{20}$. Jego autor odwołał się do biografii swojego ojca (polskiego Żyda, więźnia

nia, Ostrołęka czy Siedlce. Dwa lata później „Tadek” wydał album Niewygodna prawda II. Burza 2014. Od tego czasu „Tadek” zaniechał konstruowania i przekazywania „pamięci komunikatywnej” swojej subkulturowej wspólnoty na rzecz budowy „pamięci kulturowej” całego narodu. Raper występował m.in. przed prezydentem Andrzejem Dudą: R. Sankowski, Jak raper Tadek trafit do Pałacu prezydenta Dudy. Poznaj nowa twarz narodowej popkultury, "Gazeta Wyborcza" 02.03.2017, http://wyborcza.pl/7,113768,21445327,jak-raper-tadek-trafil-do-palacu-prezydentadudy-poznaj-nowa.html [dostęp 30.06.2018]. Szerzej o twórczości Tadeusza Polkowskiego pisze Piotr Majewski: Rap jako muzyka tożsamościowa: od czarnego getta do polskiego pop-nacjonalizmu, https://ispan.waw.pl/journals/index.php/sn/article/view/sn.2015.053/0 [dostęp 30.06.2018].

16 Patrz: Antologia polskiego rapu, red. D. Węcławek, M. Flinta, T. Kleyff, A. Cały, K. Jaczyński, Warszawa 2014.

17 Hip-hop w Polsce. Od blokowisk do kultury popularnej.

18 P. „Lex” Masłowski, Marvell - historia komiksu, http://www.marvelcomics.pl/publicism/ index/id/1006 [dostęp 30.06.2018].

19 P. Timofiejuk, Polski komiks jako narzędzie propagandy, w: KOntekstowy MIKS. Przez opowieści graficzne do analiz kultury wspótczesnej, red. G. Gajewska, R. Wójcik, Poznań 2011, s. 179-197.

20 A. Spiegelman, Maus. Opowiadanie ocalałego. Wydanie zbiorcze, przeł. P. Bikont, Warszawa 2016. 
obozu w Auschwitz) i do własnych przeżyć - za ich pomocą udało mu się opowiedzieć o doświadczeniu Holocaustu, o traumie, z którą muszą mierzyć się dwa pokolenia: Ocalałych oraz ich dzieci ${ }^{21}$.

\section{Od „blokowisk” do kanonu}

Zrozumiała i atrakcyjna forma sprawiają, że media takie jak komiks i hip-hop mogą dotrzeć do większej liczby odbiorców, dlatego chętnie po nie sięgają rozmaite instytucje, które za pomocą tego rodzaju przekazów transferują znajdujące się $\mathrm{w}$ archiwach - rozumianych jako dosłowne lub kulturowe miejsca przechowywania/magazynowania zasobów pamięciowych treści do pamięci funkcjonalnej, co otwiera możliwość ich kanonizacji ${ }^{22}$. Należy się jednak zastanowić, czy w przypadku popkulturowych form pamięci kanonizacja - a więc wybór określonych treści pod kątem ich atrakcyjności dla danej wspólnoty - przebiegać będzie w sposób opisany przez Aleidę Assmann. Wyróżniła ona trzy kluczowe dziedziny aktywnej pamięci kulturowej: religię, sztukę i historię. O samym procesie kanonizacji badaczka pisze:

Cokolwiek weszło do aktywnej pamięci, przeszło proces surowej selekcji, który zapewnia określonym dziełom trwałe miejsce w pracującej pamięci kulturowej społeczeństwa. Ów proces nazywany jest włączeniem do kanonu. Termin ten oznacza "uświęcenie”. Aby nadać tekstom, osobom, przedmiotom i pomnikom taki status, należy wyróżnić je spośród reszty jako te, które mają największe znaczenie i wartość 23 .

Niezbędnymi elementami kanonizacji są zatem: selekcja, dowartościowanie i trwanie. Przy czym selekcja w ujęciu Assmann odbywa się przy udziale ważnych instytucji, np. muzeów, i zakłada „podejmowanie decyzji i konflikty władzy"; przypisanie wartości to nadawanie obiektom czcigodności, a trwanie trzeba traktować jako główny cel całego procesu. Assmann wprost zauważa, że kanon to nie lista przebojów, ,jest natomiast niezależny od przemian historycznych i odporny na zmiany gustu społeczeństwa" ${ }^{24}$. Ta zasada sprawdza się w przypadku tekstów kultury wysokiej, ale czy dotyczy „patriotycznego rapu” lub „biało-czerwonych” komiksów, jeśli powstają one „na

21 J. Czaja, W poszukiwaniu śladów przeszłości - komiks jako medium małej i wielkiej historii, „Images" 2015, nr 26, s. 1.

22 A. Assmann, Kanon i archiwum, przeł. A. Konarzewska, w: tejże, Między historia a pamięcia. Antologia, s. 74-89.

23 Tamże, s. 80.

24 Tamże, s. 81. 
zamówienie" instytucji odpowiedzialnych $\mathrm{w}$ danym momencie za politykę historyczną państwa bądź jako oddolna inicjatywa artystyczna? Kto inny dokonuje $\mathrm{w}$ tym przypadku kanonizacji: nie jest to grono specjalistów $\mathrm{z}$ danej dziedziny, placówki kultury w sposób długofalowy dbające o przechowywanie śladów przeszłości, ani instytucje (sakralne lub świeckie), którym można przypisać troskę o ciągłość tradycji lub choćby polityki historycznej. Przeciwnie, one wszystkie tworzą dziś klientelę „mediów trywialnych", a rolę pracowników pamięci, przenoszących reprezentacje przeszłości „z magazynów do sal wystawienniczych", a więc z memorialnej strefy biernej do czynnej, tożsamościowej i wspólnototwórczej, przejmuje Internet i platformy służące do udostępniania muzyki (np. You Tube). Sieć stała się nieskończenie wielką powierzchnią wystawienniczą, a egalitarny odbiorca, wielokrotnie pobierający i odtwarzający pliki, tym samym zaś decydujący o popularności (wyborze) danego przekazu ${ }^{25}$, bierze udział w procesie kanonizacji. Zakładając, że podobne przesunięcie ma miejsce, utwory funkcjonujące jako klasyczne dla np. „patriotycznego rapu” spełniają dwa z trzech, wskazanych przez Aleidę Assmann, kryteriów, jakim podlega dzieło kanoniczne: po pierwsze nakaz selekcji, którą określony wytwór popkultury przechodzi, po drugie - wartości (przynajmniej sytuacyjnej), ponieważ osoby słuchające danego utworu robią to dlatego, że jest dla nich $\mathrm{w}$ danym momencie ważny z powodów poznawczych, estetycznych czy emocjonalnych. Będzie natomiast tym wytworom brakowało cechy trwałości, chociażby $\mathrm{z}$ tego względu, że Internet jest obecny $w$ naszym życiu od niedawna ${ }^{26}$. Jednakże bez względu na to, czy wytwory popkultury kiedykolwiek przejdą analogiczny w stosunku do tekstów kultury proces kanonizacji, nie można zaprzeczyć, że mają znaczący wpływ na kształtowanie pamięci zbiorowej i nie zauważać tej ich roli.

\section{Pamięć w formie pocztówki}

Komiks i hip-hop pełnią funkcję nie tylko mediów pamięci narodowej, ale działają również $w$ obrębie pamięci regionalnych. Na podlaskim gruncie z siły przekazu i zasięgu kultury popularnej korzystają hip-hopowcy, np. popularny raper Łukasz Szymański „Lukasyno”, którego utwory mają często

25 Dla przykładu teledysk „Tadka” do utworu Żotnierze wyklęci na You Tubie miał już ponad 2 miliony odsłon, podobną "klikalność” w granicach 1 miliona bądź 1,5 miliona mają inne utwory patriotyczne np. zrealizowane w ramach projektu „Panny Wyklęte”.

26 W Polsce Internet jest dostępny od 1994 roku. 
ponad 500 tys. odsłon na You Tubie, a który wciela się w rolę strażnika polskich wartości, wplatając je w kontekst lokalny ${ }^{27}$. Do mediów kultury popularnej odwołują się też regionalne instytucje muzealne, np. Muzeum Wojska Polskiego w Białymstoku, które zrealizowało m.in. komiks o Danucie Siedzikównie „Ince”. Wykorzystują je także władze miejskie oraz wojewódzkie $\mathrm{w}$ celu promocji regionu ${ }^{28}$.

Niezależnie od tych jednostkowych realizacji, w popkulturowe media pamięci inwestuje również samo miasto Białystok, czego przykładem jest wydany w 2015 roku dzięki środkom ze Stypendium Prezydenta Miasta Białegostoku $^{29}$ - album działającego od ponad dekady na białostockiej scenie muzycznej rapera o pseudonimie "Cira" (właściwie Marcina Ciruka) Pocztówki z Miasta B. Przy czym użyty przeze mnie czasownik „inwestują" nie jest przypadkowy, bo o płycie "Ciry" władze miasta wyrażały się w następujący sposób: „Płyta wydana przez Michała Ciruka to doskonały przykład na to, jak dobrym i pożytecznym pomysłem są stypendia artystyczne prezydenta Białegostoku. Jest to twórczość niewątpliwie wartościowa, jednocześnie promująca nasze miasto" 30 .

Muzycznym pocztówkom "Ciry" chciałabym przyjrzeć się bliżej w kontekście innej popkulturowej formy pamięci o niemal identycznym tytule: Pocztówek z Biategostoku Joanny Karpowicz - wydanej trzy lata wcześniej (2012) komiksowej opowieści o mieście oglądanym przez osobę przyjezdną. Komiks Karpowicz również powstał przy wsparciu instytucji miejskiej, tj. Centrum Ludwika Zamenhofa, obecnie wchłoniętego - mimo protestów białostoczan upatrujących $\mathrm{w}$ tej restrukturyzacji działań likwidatorskich wo-

27 Łukasz Szymański „Lukasyno” jest autorem m.in. piosenki Pytasz synku, promującej film Wyklęty w reż. Konrada Łęckiego. Zob. M. Kawczyńska, Moda czy potrzeba serca, https://tygodnik.tvp.pl/29116361/moda-czy-potrzeba-serca-czyli-bialoczerwony-rap; J. Sikora, Młodzież wspólnie z biatostockim raperem Lukasyno nagrała piosenkę o Sybirakach, materiał radiowy wyemitowany 17.10.2017, http://www.radio.bialystok.pl/wiadomosci/index/id/148691 [dostęp 30.06.2018].

28 J. Panek, Nasze województwo zareklamuje się poprzez komiks. Będą dowcipne dialogi i czarownice w stylu... Lary Croft, http://www.echodnia.eu/strefa-biznesu/firma/a/nasze-wojewodztwozareklamuje-sie-poprzez-komiks-beda-dowcipne-dialogi-i-czarownice-w-stylu-lary-croft,10315 650/ [dostęp 30.06.2018].

29 Stypendia te mają charakter indywidualny i są przyznawane wyłącznie na wykonanie $\mathrm{w}$ ustalonym czasie określonego przedsięwzięcia w następujących dziedzinach: fotografia, literatura, muzyka, opieka nad zabytkami, sztuka estradowa, sztuka filmowa, sztuki wizualne, taniec, teatr i upowszechnianie kultury. W 2018 roku Prezydent Miasta Białegostoku przyznał Michałowi Cirukowi stypendium, w ramach którego raper stworzy kontynuację płyty Pocztówki $z$ miasta $B$.

30 http://www.poranny.pl/wiadomosci/bialystok/art/9285669,cira-pocztowki-z-miasta-b-pi erwsza-pocztowka-teledysk-youtube-wideo,id,t.html [dostęp 30.06.2018]. 
bec stawiającej na wielokulturowość placówki - przez Białostocki Ośrodek Kultury ${ }^{31}$. Jak zapowiada autorka komiksu

[Pocztówwki z Biategostoku - dop. M.R.] to moja osobista próba interpretacji spotkania z miastem, zrealizowana dzięki Centrum Ludwika Zamenhofa, które zaprosiło mnie na pobyt twórczy, tych, którzy będą się doszukiwać w tej publikacji fabuły, historii, akcji z góry przepraszam za rozczarowanie. Na pocztówkach zwykle niewiele się dzieje ${ }^{32}$.

Nie sposób stwierdzić, czy "Cira” inspirował się komiksem Karpowicz, ani czy płyta rapera jest odpowiedzią na jej Pocztówki bądź ich kontynuacją, ale zestawienie tych dwóch projektów uważam za uzasadnione ze względu choćby na wspólną im cechę gatunkową, a więc przyjęcie formy „pocztówki”. Sugeruje ona folderowy charakter i skrótowość wypowiedzi, co poświadcza już przytaczana wyżej wypowiedź Karpowicz.

Kartki pocztowe to obrazki wyidealizowane, produkowane dla turystów, którzy - zabierając je ze sobą lub wysyłając bliskim i znajomym - rozprzestrzeniają emblematyczny wizerunek miejsca zaprezentowany na kartce. Jest to forma znana od dawna - graficzne przedstawienia panoramy krajobrazu pojawiają się już $w$ średniowieczu, ale prawdziwy rozkwit popularności pocztówki przypada na XVIII wiek - zmienia się wówczas koncepcja podróży, rozwija się turystyka, szczególnie uzdrowiskowa. Co ważne, karta pocztowa nabiera znaczenia dopiero wtedy, kiedy zostanie włączona w obieg społeczny (ktoś ją kupi, wyśle, zatrzyma na pamiątkę). Pocztówkę jako formę graficzną przedstawiającą obraz miasta wyróżnia idealizacja przestrzeni z wykorzystaniem klasycznych ujęć: panoramy, zdjęć ważnych budynków lub ich fragmentów, a jej istotna funkcja wiąże się „kreowaniem wizualności miasta i jego wizualnej konsumpcji" ${ }^{33}$. Zwykle na pocztówce widać więc zdefragmentowane, fikcyjne miasto bez mieszkańców. Biorąc pod uwagę te wyróżniki gatunkowe, można się domyślać, że ani płyta "Ciry", ani komiks Karpowicz z założenia nie miały być pogłębioną analizą procesów, które zachodzą na pograniczu kultur (na tej lokacji zasadza się

\footnotetext{
31 E. Sadowska-Dubicka, Centrum im. Ludwika Zamenhofa do likwidacji. Jest już sprzeciw, www.BiałystokOnline. pl 04.19.2016, http://www.bialystokonline.pl/centrum-im-ludwika-za menhofa-do-likwidacji-jest-juz-sprzeciw,artykul,91151,1,204.html; A. Domanowska, Los Centrum im. Zamenhofa w rękach radnych. Likwidacja oprotestowana, "Gazeta Wyborcza" 25.04.2016, http://bialystok.wyborcza.pl/bialystok/1,35241,19970345,los-centrum-im-zamenhofa-w-rekach -radnych-likwidacja-oprotestowana.html [dostęp 30.06.2018].

32 J. Karpowicz, Pocztówki z Białegostoku, Białystok 2012, s. 1.

33 M. Kowalewski, Jakie miasto widać na widokówce?, w: Wizualność miasta. Wytwarzanie miejskiej ikonosfery, red. M. Krajewski, Poznań 2007, s. 136-145.
} 
w dużej mierze specyfika Białegostoku), lecz uproszczonym obrazem miasta. Omawiane utwory nie realizują wszystkich cech formy pocztówki, chociażby tej, że na kartce pocztowej nie znajdziemy sylwetek ludzkich: autorzy w swoich Pocztówkach umieścili bowiem białostoczan. U Karpowicz są to anonimowe postaci zaczerpnięte $\mathrm{z}$ życia codziennego miasta, np. zaokrąglony, przyjazny mufti, wyglądające na sympatyczne i szczęśliwe katolicko-prawosławne małżeństwo, symbolizujące zrealizowaną ideę wielokulturowości, "pani w pociągu" czy "pan pijący piwo", który odwiedza cmentarz ewangelicki. "Cira" bohaterami swoich utworów (prócz samego siebie) czyni osoby historyczne, m.in. Ludwika Zamenhofa czy Icchocka Malmeda, ale tu również można odnieść wrażenie, że postaci te pełnią funkcję symboli określonych postaw lub wartości, nie są to więc konkretni mieszkańcy, tylko ich typy.

Co znamienne, do elementów łączących oba utwory należy również zdefiniowanie Białegostoku przez zjawisko wielokulturowości oraz związane z nim osoby i topografie. Na te ostatnie składają się w dużej mierze miejsca pamięci w znaczeniu przestrzennym i kulturowym, tak, jak je rozumiał Pierre Nora ${ }^{34}$. Zarówno "Cira”, jak i Karpowicz w swoich przekazach założyli, że w zróżnicowanym pod względem narodowościowym i religijnym Białymstoku istnieją miejsca pamięci wspólne wszystkim mieszkańcom i są nimi m.in. nekropolie, np. cmentarz żydowski, cmentarz ewangelicki, oraz wspólne „nie-miejsca pamięci”, takie jak teren byłego getta ${ }^{35}$. Warto sobie jednak postawić pytanie o zasadność podobnego założenia. Czy w położonym na pograniczu mieście, w którym żyją mówiący różnymi językami przedstawiciele wielu kultur i religii w ogóle można zakładać funkcjonowanie lieux de mémoire $\mathrm{w}$ takim znaczeniu, $\mathrm{w}$ jakim rozumie je Pierre Nora? Określa on tym mianem miejsca służące danej, lecz pojętej homogenicznie, wspólnocie - jak naród, rodzina, grupa etniczna, partia - do przechowywania jej pamiątek lub uznane przez nią za niezbywalną część tożsamości zbiorowej: miejsca topograficzne, monumenty (pomniki, cmentarze, architektura) czy w końcu miejsca symboliczne. Zatem, czy np. dla mieszkających w Białymstoku Białorusinów cmentarz żydowski będzie także ICH miejscem pamięci? A jeśli nawet okaże się, że tak, czy można stwierdzić, że będzie ono oznaczało dla nich to samo, co dla Polaków, Ukraińców i samych Żydów?

34 P. Nora, Między pamięciq̨ a historią: Les Lieux de Mémoire, przeł. M. Sugiera, „Didaskalia” 2011, nr 105.

35 R. Sendyka, Miejsca, które straszą (afekty i nie-miejsca pamięci), „Teksty Drugie” 2014, nr 1, s. $84-102$. 
Pogranicze jest przede wszystkich obszarem przenikania się wpływów kulturowych i polem walki z różnymi systemami uzależnienia ${ }^{36}$, natomiast koncepcja miejsc pamięci Nory - jak zauważają dzisiaj pamięcioznawcy to projekt zorientowany „na historię narodową i brak w nim uwzględnienia kluczowych dla kształtowania się francuskiej tożsamości zbiorowej procesów historycznych, takich jak chociażby imigracja czy (de)kolonizacja" ${ }^{37}$. Czyli z założenia nie uwzględnia on również specyfiki obszarów niejednorodnych, styków kulturowych, do których badania i opisywania należałoby raczej wykorzystywać takie kategorie, jak: „diaspora, hybrydyczność, pogranicze, mimikra, strategiczny esencjalizm, duża rola »historii oralnej«, kultury popularnej, emocje, empatia" 38 . W Pocztówkach obydwojga autorów trudno znaleźć próbę opisu złożoności pogranicza (nie pozwala na to przede wszystkim ukierunkowana na krótki i zrozumiały przekaz forma) i jego polifonicznego charakteru.

Podstawową i podkreślaną różnicą pomiędzy komiksowymi Pocztówkami Karpowicz i muzycznymi "Ciry" jest usytuowanie narratora. Komiks stworzyła artystka z Krakowa, która, jak podkreślało w materiałach promocyjnych Centrum im. Ludwika Zamenhofa, ma „zupełnie inne [niż mieszkańcy - dop. M.R] podejście do naszego miasta. Pocztówki z Białegostoku to próba spojrzenia oczami człowieka z zewnątrz" 39. "Cira" natomiast jest białostoczaninem i w tekstach na płycie wielokrotnie powraca do swojej lokalnej i wyrazistej tożsamości:

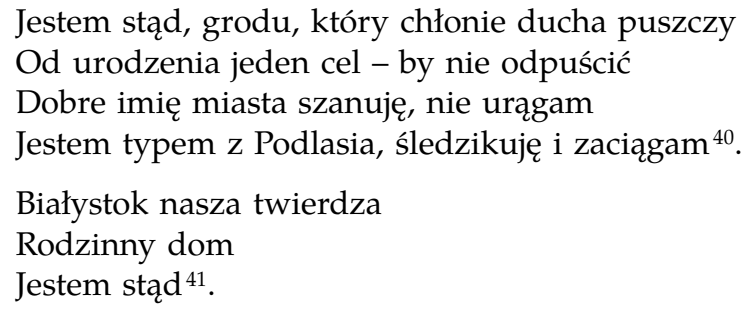

\footnotetext{
36 E. Domańska, Epistemologie pograniczy, w: Na pograniczach literatury, red. J. Fazan, K. Zajas, Kraków 2012, s. 91; E. Rybicka, Ponowoczesny regionalizm i badania komparatystyczne, „Rocznik Komparatystyczny" 2011, nr 2, s. 141-161.

37 M. Saryusz-Wolska, Zapomnieć się w pamięci, „Kultura Współczesna” 2010, nr 1, s. 10.

38 E. Domańska, Epistemologie pograniczy, s. 101.

39 A. Kopeć, Centrum Zamenhofa: Joanna Karpowicz zrobiła komiks o Białymstoku, „Kurier Poranny" 12.09.2012, http://www.poranny.pl/archiwum/art/5478716,centrum-zamenhofa-joanna -karpowicz-zrobila-komiks-o-bialymstoku,id,t.html [dostęp 30.06.2018].

40 M. Ciruk „Cira” ft. „Lukasyno”, Nasza Twierdza, w: tegoż, Pocztówki z Miasta B., Białystok 2015.

41 Tamże.
} 
Raper w programowy wręcz sposób ustanawia więc perspektywę autobiograficzną i emocjonalnie zaangażowaną $\mathrm{w}$ stosunku do opisywanych miejsc, stawiając się jednocześnie w pozycji kogoś, kto walczy o zachowanie tutejszych wartości, takich jak wiara, przywiązanie do "małej ojczyzny” i patriotyzm (nie tylko ten lokalny). Białystok w utworach CIRY staje się $z$ jednej strony przykładem miasta, w którym funkcjonują obok siebie przedstawiciele wielu wyznań - widać to np. w tekście i teledysku Moje małe sanktuaria - z drugiej jednak jest „twierdzą" - ostoją wiary i wychowania chrześcijańskiego, gdzie krzyż ciągle ma duże, intymne wręcz znaczenie:

Szukam iskry, chcę ją odzyskać

$\mathrm{W}$ małych sanktuariach

Zanim was opuszczę

Krzyżyk w pokoju i obrazek nad łóżkiem ${ }^{42}$.

Autorkę krakowską, która - jak sama przyznaje - nie znała Białegostoku przed przyjazdem, interesowała przede wszystkim wielokulturowość promowana przez miasto jako jego znak rozpoznawczy. Działania władz wszędzie powiązane są z polityką miejsca i polityką pamięci (czyli inicjatywami podejmowanymi intencjonalnie i posiadającymi publiczną legitymizację) w celu utrwalenia, usunięcia lub redefinicji określonych treści pamięci społecznej ${ }^{43}$. W oficjalnych materiałach promocyjnych stolicy Podlasia można przeczytać:

Pozycjonowanie Białegostoku kładzie nacisk na „żywą wielokulturowość”, jest to bowiem jedyne tej wielkości miasto w Polsce, w którym mamy do czynienia z żywą, czyli aktualną i autentyczną mieszanką języków, kultur i religii. Inaczej rzecz ujmując, Białystok to miasto, które historycznie, geograficznie i społecznie ma najciekawszą w Polsce sytuację w modnym obszarze komunikacji międzykulturowej ${ }^{44}$.

Ukierunkowana $\mathrm{w}$ ten sposób i legitymizowana przez władze wiedza, przekształcona $\mathrm{w}$ aktywną politykę pamięci o szerokim zasięgu, sprawia, że przybysze interesujący się miastem lub odwiedzający Białystok skupiają się najpierw i przede wszystkim na osobistym sprawdzeniu „żywej wielokulturowości" ${ }^{45}$. Pragnienie doświadczenia wielokulturowości bazuje

\footnotetext{
42 M. Ciruk „Cira” ft. D. Pietraszuk, Moje małe sanktuaria, tamże.

43 E. Rybicka, Geopoetyka. Przestrzeń i miejsce we wspótczesnych teoriach i praktykach literackich, Kraków 2014.

44 www.bialystok.pl [dostęp 27.07.2018].

45 „Wielokulturowość” sprawdzała m.in. Agnieszka Korytkowska-Mazur, dyrektor Teatru Dramatycznego im. Aleksandra Węgierki w Białymstoku w latach 2012-2016. Więcej na temat jej działalności artystycznej: http://www.encyklopediateatru.pl/osoby/43245/agnieszkakorytkowska-mazur [dostęp 23.07.2018].
} 
jednak na określonym jej wyobrażeniu, sprowadzającym to złożone zjawisko do rodzaju atrakcji turystycznej, którą można napotkać na szlaku, a następnie poznać bez zbędnych przygotowań i trudu. Współistnienie wielu kultur ma zapewne przypominać to, co przybysze widzą w materiałach promocyjnych (a więc zgodne, bo papierowe, sąsiedztwo), władze zaś podczas jarmarków oraz festiwali folklorystycznych, kiedy podziwiają występy odświętnie ubranych oraz wzajemnie życzliwych zespołów i artystów. Tymczasem wielość kultur występujących na danym terenie to jeszcze nie wielokulturowość i nie sposób w „pocztówkowej” formie pokazać, jak ona funkcjonuje w praktyce, na co dzień. Paradoks polega na tym, że w folderach reklamowych zawsze będzie tylko folderowa wielokulturowość, której turysta nie napotka w rzeczywistości, z kolei zaś ta realna - trudna i żmudna - nie wypadnie dobrze w prospekcie ${ }^{46}$.

Kłopoty z wielokulturowością nie dotyczą tylko przyjezdnych, miewają je również tubylcy. W jednym ze swoich artykułów Krzysztof Zajas pytał, czy nie jest ona przypadkiem kolejnym mitem, utopią, która ma służyć zbiorowej identyfikacji. Zauważył przy tym, że wielokulturowość pseudonimuje relacje centroperyferyjne: „Stwarza złudzenie porozumienia z Innym, na podstawie wspólnego doświadczenia przestrzeni, ale tak naprawdę jest kolejną narracją o sobie, monologiem dyskursu centralnego" ${ }^{47}$. Badacz podkreśla utopijny, a zarazem obronny charakter tej narracji w naszym kraju:

Mówiąc o wielokulturowości, Polacy z reguły odwołują się do dwóch ustalonych jako pewniki faktów z historii. Pierwszy z nich to wielokulturowość dawnej Rzeczypospolitej szlacheckiej, w której funkcjonowały obok siebie różne narodowości, wyznania, języki, a na szczególne podkreślenie zasługuje wielowiekowa tolerancja wobec Żydów. Drugi mówi o wieloetniczności przedwojennej Polski, scalającej z trudem odmienne kulturowo terytoria dawnych zaborów ${ }^{48}$.

Zdaniem Zajasa Polacy, tworząc wielokulturową narrację, reagują na prawdziwe bądź wyimaginowane zarzuty dotyczące nietolerancji, zaś jej zaprzeczeniem ma być istnienie niejednorodnych pod względem etnicznym, religijnym i językowym regionów. Utopijna idea "żywej wielokulturowości", podjęta przez władze Białegostoku i Podlasia, byłaby więc (idąc tym tropem) próbą sprostania wymaganiom "centrum" i kultury "ogólnoeuropejskiej” 49.

\footnotetext{
46 O folderowej wielokulturowości pisała Katarzyna Sztop-Rutkowska m.in. w artykule Folderowa wielokulturowość. Wykopmy rasizm z Białegostoku, https://www.academia.edu/3717186/ Folderowa_wielokulturowo \%C5\%9B\%C4\%87 [dostęp 26.07.2018].

47 K. Zajas, Kresy skreślone, czyli o polskiej wielokulturowości, „Wielogłos” 2009, nr 5-6, s. 116.

48 Tamże, s. 118.

49 Tamże.
} 
Komiksowa podróż po mieście Joanny Karpowicz mieści się w ramach opisanego wyżej - i z góry skazanego na porażkę - sprawdzania, czy w Białymstoku rzeczywiście można doświadczyć wielokulturowości, tak jak obiecują władze miasta (i turyzm). Poprzedza ją ostrzeżenie otrzymane przez autorkę od taksówkarza jeszcze w Krakowie, który - jak mówi - z mediów wie, że „w Białymstoku chuligaństwo takie, że bój się Boga. $\mathrm{Na}$ tle rasowym. I piłkarskim podobno" ${ }^{50}$. Artystka rozpoczyna Pocztówki od naiwnego w gruncie rzeczy pytania, które wprost odnosi się do opisu miasta umieszczonego na stronie Urzędu Miejskiego w Białymstoku: „Bardzo mnie ta wielokulturowość intrygowała, czy będzie autentyczna, czy to wyłącznie teoria, na poziomie marketingowej obietnicy?" 51. Swoje oczekiwania podkreśla graficznie: na drugiej karcie komiksu widzimy ilustrację przedstawiającą umieszczone na tle polskiej flagi i ułożone $\mathrm{w}$ równym rzędzie symbole religijne charakterystyczne dla katolicyzmu, prawosławia, judaizmu, protestantyzmu i islamu, mające uobecniać ideę „żywej wielokulturowości". Obietnica zostaje poddana w wątpliwość już w pociągu, podczas rozmowy z podróżującą z Warszawy białostoczanką: „Tatarzy są, ale raczej nie w Białymstoku. Bohoniki, Kruszyniany. Tamte okolice. Dobrze gotują. Podobno kuchnia świetna. O ewangelikach nie słyszałam" 52.

W podróż po mieście autorka, jako osoba przyjezdna i niezaznajomiona z topografią miasta, wyrusza z mapą, którą odważa się porzucić pod koniec wędrówki - dopiero wtedy, gdy udaje jej się oswoić Białystok. Wówczas pozwala sobie na skracanie ścieżek i zbaczanie z głównych tras.

Karpowicz, posługując się mapą ${ }^{53}$, podąża tropem miejsc pamięci, jakie mają świadczyć o wielokulturowej przeszłości i tożsamości miasta. Są to np. cmentarz ewangelicki czy cmentarz żydowski oraz nie-miejsca, w rozumieniu Augé, czyli galeria handlowa, gdzie na co dzień spotykają się Polacy i Białorusini (Białystok Białorusini odwiedzają często w celu zrobienia zakupów, stąd bardzo duża liczba galerii handlowych w mieście) ${ }^{54}$.

Obserwacje artystki, dokonane podczas zwiedzania tych miejsc, skutkują odnotowywaniem braku oznak wielokulturowości: niezainteresowanie mieszkańców pomnikami historii (cmentarzem ewangelickim, żydowskim),

\footnotetext{
50 J. Karpowicz, Pocztówki z Białegostoku, s. 4.

51 Tamże, s. 5.

52 Tamże, s. 6.

53 Zob. E. Konończuk, Mapa w interdyscyplinarnym dialogu geografii, historii i literatury, „Teksty Drugie" 2011, nr 5, s. 3.

54 M. Augé, Nie-Miejsca: wprowadzenie do antropologii nadnowoczesności: fragmenty, przeł. A. Dziadek, „Teksty Drugie” 2008, nr 4, s. 127-140.
} 
niszczenie historycznego osiedla Bojary, nieobecność żydowskiej przeszłości w pamięci białostoczan czy też nieokazywanie należytego szacunku przyjezdnym sąsiadom zza wschodniej granicy. Realizowaną wielokulturowość autorka natomiast infantylizuje, czego przykład stanowi sposób, w jaki opisuje katolicko-prawosławną parę, która „ma za sobą 45 lat małżeństwa, szmat czasu i wciąż razem. Ich sekretem jest tolerancja. Ona znosi jego humory a on jej dziwactwa". Małżonkowie na co dzień przesiadują w Alei Zakochanych (alejce, która znajduje się w zlokalizowanym w centrum Białegostoku parku), wspólnie spędzają czas w kinie i teatrze, w niedzielę natomiast Ona chodzi do kościoła, a On do cerkwi. Nie ma między nimi żadnych konfliktów na tle wyznaniowym - ich życie wpisuje się w utopijne wyobrażenie o wielokulturowości, a przecież mieszkańcy Podlasia wiedzą, z jakimi problemami muszą się mierzyć mieszane małżeństwa, których rodziny nie akceptują wiary jednego z partnerów lub oni sami nie zgadzają się co do tego, gdzie ich wspólne dziecko powinno zostać ochrzczone.

Najbardziej uderzająca jest jednak nieobecność żydowskiej przeszłości, która wyraźnie zarysowuje się w epizodzie komiksu zatytułowanym Brakujacy element. Autorka, pytając "Białostoccy Żydzi - gdzie teraz jesteście?", do miejsc znanych, tłumnie odwiedzanych przez białostoczan (budka z lodami w parku Planty, Teatr Dramatyczny, Stadion "Jagiellonii") dorysowuje brakujące żydowskie postaci: duchy ${ }^{55}$. Niezrealizowaną ideę równości wielokulturowej Karpowicz interpretuje również przez nieobecność w świadomości mieszkańców miasta białych bułeczek (bialys bagels) - żydowskiego przysmaku przywiezionego do Stanów przez białostockich Żydów, który cieszy się w USA ogromną popularnością. Nie jest jednak znany w rodzinnym mieście twórcy języka esperanto Ludwika Zamenhofa. Uobecniając nieobecną pamięć o białostockich Żydach, autorka sugeruje, że w Białymstoku, zarówno w przestrzeni publicznej, jak i świadomości mieszkańców, można spotkać zazwyczaj jedynie dowody świadczące o zapominaniu żydowskiej historii miasta ${ }^{56}$. Dorysowując "brakujące elementy", zaznacza, że niegdyś tak liczni żydowscy mieszkańcy Białegostoku zniknęli ze zbiorowego wymiaru pamiętania, ale miejsca na pamięć o nich ciągle jest $\mathrm{w}$ przestrzeni publicznej i świadomości białostoczan wystarczająco dużo, należy je tylko odpowiednio wykorzystać. Myślę, że dorysowywanie „brakującego elementu” jest także sugestią, że można implantować pamięć, wprowadzając do szkół lekcje dotyczące historii regionu, obejmując instytucjonalną opieką miejsca pamięci

55 J. Karpowicz, Pocztówki z Białegostoku, s. 12.

56 D. Zawadzka, Białystok jak buza, w: Geografia wyobrażona regionu. Literackie figury przestrzeni, red. D. Kalinowski, M. Mikołajczak, A. Kuik-Kalinowska, Kraków 2014, s. 212. 
czy powołując muzeum, które dbałoby o pamięć Żydów Podlasia. Po latach takiej „pracy pamięci” wielokulturowość miałaby szansę stać się bardziej „żywa”, choć trudno wyrokować, czy atrakcyjnie wyglądałaby w folderze.

"Cira" nie korzysta z mapy, jest "stąd" (Michał Ciruk urodził się na Podlasiu), a więc trasę jego spaceru po Białymstoku wyznaczają ramy zbiorowej pamięci białostoczan oraz pamięć autobiograficzna, która nie jest prostą reprodukcją minionych wydarzeń, lecz opiera się na procesach konstrukcyjnych. Na to bowiem, w jaki sposób przypominamy sobie swoje życie, wpływają m.in. wzorce kulturowe i społeczne oraz lokalne ramy pamięci ${ }^{57}$. W utworze Hej Magdalenko opisywane wzgórze, gdzie znajduje się cerkiew św. Magdaleny - uważana za jeden z najstarszych budynków murowanych w Białymstoku - i gdzie mieścił się wielowyznaniowy cmentarz ${ }^{58}$, pełni funkcję miejsca, w którym zatrzymana została licealna przeszłość autora tekstu. W Pierwszej pocztówce odwiedza on punkty miasta dobrze znane białostoczanom i wywołujące $\mathrm{u}$ większości $\mathrm{z}$ nich podobne wspomnienia:

Gdzie była wodopojka

Sienny Rynek i ...

Mijam stary Gryf, stary Loft i Odeon

[...]

Pamiętam puste schody, za rękę brałem matkę

Kto nie bał się upiornych stopni na dworcową kładkę? ${ }^{59}$

Spacer uruchamia zatem procesy memorialne, pełni funkcję wywoławczą, podobnie jak w utworze Moje małe sanktuaria, w którym znajdujące się na trasie wędrówki świątynie i nekropolie przypominają o przodkach. Pamięć o nich autor traktuje jako warunek budowania tożsamości swojej i miasta:

Spacerem po Zwierzyńcu

Wojskowy Cmentarz

Cichy krzyż stawiam znicz

Warto pamiętać

Ta zaduma, kto umarł tu przez wojnę

Walczył godnie ${ }^{60}$.

57 K. Woniak, hasło: „Pamięć lokalna”, w: Modi Memorandi. Leksykon kultury pamięci, red. M. Saryusz-Wolska, R. Traba, Warszawa 2014.

58 J. Medek, Historia miasta zapisana w szkieletach ze wzgórza św. Magdaleny, "Gazeta Wyborcza" 25.02.2013, http://bialystok.wyborcza.pl/bialystok/1,35241,13454403,Historia_miasta_zapisana_ w_szkieletach_ze_wzgorza.html [dostęp 30.06.2018].

59 M. Ciruk "Cira”, Pierwsza pocztówka, w: tegoż, Pocztówki z Miasta B.

60 M. Ciruk "Cira", Moje małe sanktuaria, tamże. 
Przy czym pamięć ta jest oczywiście - na miarę „pocztówkowej” narracji - wybiórcza i hasłowa. "Cira” w swoich muzycznych Pocztówkach podkreśla, że pamięta, iż Wielką Synagogę w Białymstoku i zamkniętych w niej 2000 Żydów spalili Niemcy, a bohater Malmed, patron jednej $z$ ulic w centrum miasta, został zamordowany przez nazistów. W żadnym jednak ze swych utworów nie wspomina o krzywdach, które w trakcie wojny wyrządzili Żydom sami mieszkańcy Podlasia ${ }^{61}$. Oczywiście nie musi tego robić, ale pomijając tego rodzaju fakty $\mathrm{z}$ historii Białegostoku wpisuje się $\mathrm{w}$ dyskurs, który zakłada, że istnieją tylko dwa obrazy Białegostoku: jednym jest Rasistok tym mianem często określają miasto osoby z zewnątrz, które nie odnalazły tutaj wielokulturowości „folderowej”, drugim natomiast - miejsce wyidealizowane, właśnie „folderowe" i obronne (,twierdza"!), gdzie w zgodzie od pokoleń mają żyć przedstawiciele różnych kultur i religii. Kreślenie takich dystopijnych lub utopijnych wizerunków miasta nie zostawia niestety przestrzeni na dyskusję i nie pozwala na zbudowanie wiarygodnego wizerunku Białegostoku ${ }^{62}$.

Myślę, że gest „Ciry” można także rozpatrywać w proponowanej przez Zajasa optyce centroperyferyjnej: jako nawiązanie i odpowiedź na funkcjonujący w dyskursie ogólnopolskim wizerunek Białegostoku - miasta, w którym przestępstwa na tle rasistowskim zdarzają się bardzo często, a miejsca pamięci, związane z wielokulturową przeszłością, są zaniedbywane i niszczone $^{63}$. Premiera płyty miała miejsce kilka miesięcy po ukazaniu się książki Marcina Kąckiego Białystok. Biała siła, czarna pamięćc4 - reportażu o przemilczeniach i niszczeniu śladów wielokulturowości, zwłaszcza obecności Żydów ${ }^{65}$. Tezą Kąckiego jest, że celowe wymazywanie pamięci o wielokultu-

61 Zob. M. Tryczyk, Miasta śmierci. Sąsiedzkie pogromy Żydów, Warszawa 2015.

62 Pocztówki z miasta B zostały odebrane jako próba obrony miasta przed atakami z zewnątrz: „Wydaje się, że dzięki tak pozytywnemu przekazowi „Cira” stara się zmierzyć z tym wszystkim, co złego ostatnio narosło wokół naszego Miasta (po szczegóły odsyłam do książki Marcina Kąckiego)." - pisał o płycie jeden z lokalnych działaczy społecznych Radek Puśko na swoim blogu. R. Puśko, Cira i jego ",pocztówki”, w: tegoż, Blog bardzo obywatelski, wpis z 12.12.2015, http://radekpusko.pl/cira-i-jego-pocztowki/ [dostęp 27.07.2018].

63 (jsz), Rasizm w Białymstoku. Nadal dochodzi do ataków na cudzoziemców, „Kurier Poranny" 30.06.2013, http://www.poranny.pl/wiadomosci/bialystok/art/5543754,rasizm-w-bialy mstoku-nadal-dochodzi-do-atakow-na-cudzoziemcow,id,t.html; Białystok - raport MSW dot. zwalczania przestępczości zwiqzanej z dyskryminacja rasowa i ksenofobiq, https://mswia.gov.pl/pl/ aktualnosci/11975,Bialystok-raport-dotyczacy-zwalczania-przestepczosci-zwiazanej-z-dyskrym inacja-r.html [dostęp 30.06.2018].

64 M. Kącki, Białystok. Biała siła, czarna pamięć, Wołowiec 2015.

65 Nie twierdzę, że płyta stanowi bezpośrednią odpowiedź na tę książkę, ale sądzę, że książka jest niejako podsumowaniem pojawiających się w mediach opinii o Białymstoku jako mieście ksenofobicznym. 
rowych dziejach Białegostoku, wraz z aktami przemocy o charakterze nacjonalistycznym, ksenofobicznym i działalnością grup „narodowców”, do których zalicza się Młodzież Wszechpolską i Obóz Narodowo Radykalny, przekształcają miasto w "Rasistok” ${ }^{66}$. Raper nie odnosi się do Kąckiego wprost, ale podobne postrzeganie Białegostoku uważa za niesprawiedliwie - „za miłość ojczyzny nazwą faszystą" - wielokulturowość natomiast, jego zdaniem, jest realna i można obserwować ją na co dzień. Na Podlasiu nawet muzułmanie nie mogą zrobić nikomu krzywdy: „żyją tu Tatarzy nikt nie jest islamistą / Katolicy, prawosławni, starowiercy i poganie", a wielokulturowe symbole widnieją w wielu przestrzeniach miejskich „Krzyż na drzewie przy stawie na Marczukowskiej, Cerkiew św. Ducha na Antoniuku".

"Cira" nie unika dramatycznych momentów z dziejów miasta, chociaż wybiera te, które są zgodne nie tyle ze specyfiką historii regionalnej, ile narodowej. I tak spacer dawną ulicą Kupiecką - dzisiaj Malmeda - wywołuje pamięć II wojny światowej i prowadzi do rekonstrukcji dnia, w którym Niemcy przystąpili do likwidacji białostockiego getta.

Dawna Kupiecka, tu ma start ten spektakl

Wysiedlenie białostockich Żydów w paru odcinkach czeka strach czeka śmierć czeka Treblinka ${ }^{67}$.

Konstrukcja utworu jest bardzo dynamiczna i tak pomyślana, by wzbudzać silne emocje. Autor w tym krótkim, kilkuwersowym tekście kreuje, wzorowanego na realnej postaci historycznej Icchoka Malmeda, bohatera, który $\mathrm{w}$ ramach zemsty za śmierć rodziców oblewa SS-mana kwasem solnym, a następnie, w obliczu groźby masowej egzekucji, przyznaje się do winy, choć wie, że czeka go za to śmierć. W drugiej zwrotce, przywołującej wydarzenia chronologicznie starsze, przypomniana zostaje postać Ludwika Zamenhofa, który - rozumiejąc, że źródłem wrogości i konfliktów są nienawiść i brak zrozumienia - od dziecka zabiega o równość i pokój: „zdania mają w świat ponieść pojednanie a nie waśnie i podział". Wykreowany przez "Cirę" twórca języka esperanto wie jednak, że jego starania nie przyniosą oczekiwanych efektów, czego skutkiem będą wydarzenia z dziejów ponadlokalnych - II wojna światowa i Zagłada: „Esperanto estas quinko powiedział i zaszlochał". Tak zatem jak Malmed symbolizuje, nieodbiegający od wzorców narodowych, heroiczny opór wobec niemieckiego okupanta i nazisty,

66 D. Zawadzka, Między archiwum i kanonem. Praca pamięci w literaturze regionu podlaskiego na przykładzie książek z 2015 roku, w: Regionalizm literacki - historia i pamięć, red. Z. Chojnowski, E. Rybicka, Kraków 2017, s. 125.

67 M. Ciruk „Cira”, Gwiazdy Dawida, w: tegoż, Pocztówki z Miasta B. 
Zamenhof z kolei pełni funkcję symbolu idei równości, którą zniszczyła Wielka Historia.

Mając na uwadze ogromną siłę oddziaływania popkulturowych form memorialnych na kształtowanie się pamięci zbiorowej, a jednocześnie ich wyznaczniki gatunkowe (np. właściwości „pocztówki”), należy zastanowić się nad tym, na ile "media trywialne" - używając określenia Erll - pozwalają na budowanie wartościowej narracji regionalnej, np. o Podlasiu, jeśli dzieje tego regionu nie mieszczą się w schematach mainstreamowych? Czy medium przykładowej „pocztówki” umożliwia tworzenie opowieści niepolegających na przerzucaniu się argumentami, które mają dowodzić istnienia bądź nieistnienia wielokulturowości na tym obszarze, czy zapewnia w niej miejsce na pokazanie trudnej codzienności „sąsiedztwa"?

Raper, przyjmując perspektywę człowieka "stąd," reprezentuje pamięć miejscową, przypisaną wspólnocie białostoczan, ale jest to "pamięć polska” i w tym sensie bezpieczna, że zgodna z narracją ogólnonarodową. "Cira” opisuje Białystok z punktu widzenia Polaka zamieszkującego te tereny, czyli opowiada o historii większości, nie próbuje wejść w „mikrohistorię" 68 . Wiele miejsc przez niego odwiedzanych pokrywa się $\mathrm{z}$ tymi, którym przygląda się Karpowicz - obserwatorka z zewnątrz, dysponująca jedynie pamięcią kulturową, jaką zdobyła dzięki wykształceniu, lekturze i zasłyszanym opowieściom. "Cira" niektóre z nich odwiedza, by ocalić je od zapomnienia (np. teren byłego getta) i bronić Białegostoku przed zarzutami stawianymi przez centrum - rasizm, zacieranie śladów wielokulturowej przeszłości inne po to, by uruchomić osobiste, lecz również pomijające historię lokalną, wspomnienia (np. wagary w liceum). Karpowicz udaje się do tych miejsc, by swoją "folderową" wiedzę zweryfikować, ale na zasadzie potwierdzenia bądź zaprzeczenia. Co ważne, mimo że autorzy podkreślają własne - odmienne - perspektywy: „stąd” oraz „z zewnątrz”, to jednak można odnieść wrażenie, że oboje tworzą spójny, lecz jednowymiarowy obraz Białegostoku. $\mathrm{Z}$ jednej strony jest on bezkonfliktowy i sentymentalno-heroiczny, ale bazujący na ogólnonarodowych wzorach, z drugiej - melancholijno-dydaktyczny, wyrażający żal za utraconą wielokulturowością Białegostoku oraz stanowiący dyskretne napomnienie jego mieszkańców i włodarzy.

68 Zob. E. Domańska, Mikrohistorie. Spotkania w międzyświatach, Poznań 1999; R. Stobiecki, Historiografia regionalna. Nowa wizja dziejów czy nowa metoda?, w: Historie wzajemnych oddziatywań, red. R. Traba, Berlin-Warszawa 2014, s. 387-400. 
Utopie odgrywają ważną rolę w kulturze nowoczesnej, jeśli jednak pogranicze potrzebuje utopii - przeszłości lub przyszłości - to takiej, na którą składać się będą pełne napięć mikroutopie, uwzględniające jego polifoniczność ${ }^{69}$. Można powątpiewać, czy mają ona szanse zaistnieć dzięki kulturze popularnej jako medium pamięci. „Pocztówki” prowokują raczej do pogoni za utopią bezkonfliktowej wielokulturowości, wytworzonej $\mathrm{w}$ ramach mechanizmów obronnych przed zarzutami o nietolerancję i ksenofobię.

\section{Bibliografia}

Assmann Aleida (2013), Metafory, modele i media pamięci, przeł. Z. Dziewanowska-Stefańczyk, w: tejże, Między historia a pamięcia. Antologia, red. i posłowie M. Saryusz-Wolska, Warszawa: Wydawnictwa Uniwersytetu Warszawskiego, s. 89-126.

Augé Marc (2008), Nie-Miejsca: wprowadzenie do antropologii nadnowoczesności: fragmenty, przeł. A. Dziadek, „Teksty Drugie”, nr 4, s. 127-140.

Białystok - raport MSW dot. zwalczania przestępczości zwiazanej z dyskryminacja rasowa $i$ ksenofobiq (2018), https://mswia.gov.pl/pl/aktualnosci/11975,Bialystok-raportdotyczacy-zwalczania-przestepczosci-zwiazanej-z-dyskryminacja-r.html.

Bourdieu Pierre (2006), Dystynkcja. Społeczna krytyka władzy sądzenia, przeł. P. Biłos, Warszawa: Wydawnictwo Naukowe Scholar.

Ciruk Michał "Cira” ft. „Lukasyno" (2015), Pocztówki z Miasta B., Białystok.

Domańska Ewa (2012), Epistemologie pograniczy, w: Na pograniczach literatury, red. J. Fazan, K. Zajas, Kraków: Universitas, s. 85-101.

Domańska Ewa (1999), Mikrohistorie. Spotkania w międzyświatach, Poznań: Wydawnictwo Poznańskie.

Erll Astrid (2009), Literatura jako medium pamięci zbiorowej, przeł. M. Saryusz-Wolska, w: Pamięć zbiorowa i kulturowa. Wspótczesna perspektywa niemiecka, red. M. Saryusz-Wolska, Kraków: Universitas, s. 211-248.

Jutkiewicz Michał (2017), Paradoks dystynkcji. Komiks na rynku kultury w Polsce, „Teksty Drugie", nr 5, s. 88-107.

Kałążny Jerzy (2007), Kategoria pamięci zbiorowej w badaniach literaturoznawczych, „Kultura Współczesna", nr 3, s. 85-103.

Karpowicz Joanna (2011), Pocztówki z Białegostoku, Białystok: Centrum Ludwika Zamenhofa.

Kącki Marcin (2015), Białystok. Biała siła, czarna pamięć, Wołowiec: Czarne.

Konończuk Elżbieta (2011), Mapa w interdyscyplinarnym dialogu geografii, historii i literatury, „Teksty Drugie”, nr 5, s. 255-264.

Kopeć Anna (2018), Centrum Zamenhofa: Joanna Karpowicz zrobita komiks o Białymstoku, „Kurier Poranny” 12.09.2012, http://www.poranny.pl/archiwum/art/5478716, centrum-zamenhofa-joanna-karpowicz-zrobila-komiks-o-bialymstoku,id,t.html.

69 R. Traba, Polifonia pamięci, w: tegoż, Przeszłość w teraźniejszości. Polskie spory o historię na początku XXI wieku, Poznań 2009. 
Kurz Iwona (2007), Przepisywanie Pamięci. Przypadek Muzeum Powstania Warszawskiego, „Kultura Współczesna”, nr 3, s. 150-162.

Masłowski „Lex” Paweł (2018), Marvell - historia komiksu, http://www.marvelcomics. $\mathrm{pl} / \mathrm{publicism/index/id/1006.}$

Medek Jakub (2018), Historia miasta zapisana w szkieletach ze wzgórza św. Magdaleny, „Gazeta Wyborcza” 25.02.2013, http://bialystok.wyborcza.pl/bialystok/1,35241, 13454403,Historia_miasta_zapisana_w_szkieletach_ze_wzgorza.html.

Nora Pierre (2011), Między pamięciq a historią: Les Lieux de Mémoire, przeł. M. Sugiera, „Didaskalia. Gazeta Teatralna”, nr 105, s. 20-27.

Puśko Radek (2018), Cira i jego "pocztówki”, w: tegoż, Blog bardzo obywatelski, wpis z 12.12.2015, http://radekpusko.pl/cira-i-jego-pocztowki/.

Rasizm w Białymstoku. Nadal dochodzi do ataków na cudzoziemców (2018), „Kurier Poranny" 30.06.2013, http://www.poranny.pl/wiadomosci/bialystok/art/5543754, rasizm-w-bialymstoku-nadal-dochodzi-do-atakow-na-cudzoziemcow,id,t.html.

Rybicka Elżbieta (2014), Geopoetyka. Przestrzeń i miejsce we współczesnych teoriach i praktykach literackich, Kraków: Universitas.

Rybicka Elżbieta (2011), Ponowoczesny regionalizm i badania komparatystyczne, „Rocznik Komparatystyczny", nr 2, s. 141-161.

Saryusz-Wolska Magdalena (2010), Zapomnieć się w pamięci, „Kultura Współczesna”, nr 1, s. 76-86.

Sendyka Roma (2014), Miejsca, które straszq (afekty i nie-miejsca pamięci), „Teksty Drugie", $^{\prime \prime}$ 1, s. 84-102.

Skrzypczyk Krzysztof (2018), Komiksologia, czyli komiks w ujęciu teoretyczno-badawczym, http://www.zeszytykomiksowe.org/sklad/skrzypczyk-sympozja.pdf.

Spiegelman Art (2016), Maus. Opowieść Ocalałego. Wydanie zbiorcze, przeł. P. Bikont. Warszawa: Prószyński Media.

Stobiecki Rafał (2014), Historiografia regionalna. Nowa wizja dziejów czy nowa metoda?, w: Historie wzajemnych oddziaływań, red. R. Traba, Berlin-Warszawa: Narodowe Centrum Kultury, s. 387-400.

Szacka Barbara (2010), II wojna światowa w pamięci rodzinnej, w: Między codziennościa a wielka historią. Druga wojna światowa w pamięci zbiorowej społeczeństwa polskiego, red. P.T. Kwiatkowski, L.M. Nijakowski, B. Szacka, A. Szpociński, Gdańsk-Warszawa: Wydawnictwo Naukowe Scholar, s. 81-132.

Sztop-Rutkowska Katarzyna (2018), Folderowa wielokulturowość. Wykopmy rasizm z Białegostoku, https://www.academia.edu/3717186/Folderowa_wielokulturowo\%C5 $\% 9 \mathrm{~B} \% \mathrm{C} 4 \% 87$.

Timofiejuk Paweł (2011), Polski komiks jako narzędzie propagandy, w: KOntekstowy MIKS. Przez opowieści graficzne do analiz kultury współczesnej, red. G. Gajewska, R. Wójcik, Poznań: Wydawnictwo Poznańskiego Towarzystwa Przyjaciół Nauk, s. $179-197$.

Traba Robert (2009), Polifonia pamięci, w: tegoż, Przeszłość w teraźniejszości. Polskie spory o historię na początku XXI wieku, Poznań: Wydawnictwo Poznańskie.

Tryczyk Michał (2015), Miasta śmierci. Sąsiedzkie pogromy Żydów, Warszawa: Wydawnictwo RM. 
Woniak K. (2014), hasło: „Pamięć lokalna”, w: Modi Memorandi. Leksykon kultury pamięci, red. M. Saryusz-Wolska, R. Traba, Warszawa: Wydawnictwo Naukowe Scholar.

Wójtowicz Stanisław (2014), O kierunkach badań literaturoznawczych nad hip-hopem, w: Hip-hop w Polsce. Od blokowisk do kultury popularnej, red. M. Miszczyński, Warszawa: Wydawnictwa Uniwersytetu Warszawskiego, s. 183-198.

Zajas Krzysztof (2009), Kresy skreślone, czyli o polskiej wielokulturowości, „Wielogłos”, nr 5-6, s. 110-121.

Zawadzka Danuta (2014), Białystok jak buza, w: Geografia wyobrażona regionu. Literackie figury przestrzeni, red. D. Kalinowski, M. Mikołajczak, A. Kuik-Kalinowska, Kraków: Universitas, s. 201-216.

Zawadzka Danuta (2017), Między archiwum i kanonem. Praca pamięci w literaturze regionu podlaskiego na przykładzie książek z 2015 roku, w: Regionalizm literacki - historia i pamięć, red. Z. Chojnowski, E. Rybicka, Kraków: Universitas, s. 125-154. http://www.encyklopediateatru.pl/osoby/43245/agnieszka-korytkowska-mazur (2018).

\section{Popculture as the Medium of Regional Remembrance in Białystok}

\section{Summary}

The author chose popular culture texts such as graphic novel and hip-hop album to analyze the process of remembering in the region of Podlasie. The article also examines whether popular media have the potential to create place narration as well as to present the commonplace tensions that emerge from the cultural and religious diversity where distinct "memories" blend.

Keywords: memory, cultural diversity, new regionalism, geopoetics, pop culture 